\title{
Ecoregional distribution of potentially useful species of Araceae and Bromeliaceae as non-timber forest products in Bolivia
}

\author{
Amparo Acebey • Thorsten Krömer • Brigitte L. Maass • \\ Michael Kessler
}

Received: 29 October 2009/Accepted: 28 April 2010/Published online: 19 May 2010

(C) The Author(s) 2010. This article is published with open access at Springerlink.com

\begin{abstract}
In Bolivia, the plant families Araceae and Bromeliaceae offer numerous nontimber products, including ornamental plants, medicines, foods, and fibers. The economic potential for the utilization of these resources depends critically on the distribution of potentially useful species in different ecoregions in Bolivia. We conducted both a bibliographical revision of uses and ecological field work at 43 sites in the Bolivian Andes and lowlands to assess the potential for sustainable use as suggested by the Rapid Vulnerability Assessment method. The ecological criteria used for the evaluation were abundance (frequency), life form, geographical distribution, and habitat preference. We found that Bolivia has a striking number of potentially useful species of both families but that their potential use differs among ecoregions. Araceae were most species-rich and frequent in the humid lowland and montane forests. In these ecoregions, this family has a particular local importance mainly as traditional medicines and a great potential as ornamental plants. In contrast, economically useful bromeliads are best represented in seasonally dry forest habitats, especially for the production of fibres. Many species of bromeliads, which also occur in humid montane forests, although rare, are potentially important for commercialisation as ornamental species. This study shows that the uses of Araceae and Bromeliaceae are manifold and could be greatly increased through efficient management, although with different strategies according to the different ecoregions.
\end{abstract}

\footnotetext{
A. Acebey $(\bowtie) \cdot T$. Krömer

Centro de Investigaciones Tropicales, Universidad Veracruzana, Interior de la Ex-hacienda Lucas Martín, Privada de Araucarias s/n, Col. 21 de Marzo, 91019 Xalapa, Veracruz, Mexico e-mail: cacebey@gmx.net
}

\section{B. L. Maass}

Department of Crop Sciences: Agronomy in the Tropics, Georg-August University of Göttingen, Grisebachstr. 6, 37077 Göttingen, Germany

Present Address:

B. L. Maass

CIAT-TSBF, P.O. Box 30677, Nairobi, Kenya

M. Kessler

Systematic Botany, University of Zürich, Zollikerstrasse 107, 8008 Zürich, Switzerland 
Keywords Aroids $\cdot$ Bolivia $\cdot$ Bromeliads $\cdot$ Ecoregions $\cdot$ Non-timber forest products · Potential uses $\cdot$ Species distribution

\section{Introduction}

In the face of the ongoing unabashed destruction and degradation of tropical forests, one of the most promising approaches to their conservation appears to be the harvest of nontimber forest products by the local inhabitants (Peters et al. 1989; Phillips et al. 1994; FAO 1995, 1996; Villalobos and Ocampo 1997). Millions of people worldwide depend on the harvest of non-timber forest products for their livelihoods (Vedeld et al. 2004), as these products include, e.g., food, traditional medicines, construction materials, and fibers (De Beer 1990; Akerele et al. 1991; Panayotou and Ashton 1992; FAO 1995; Belcher 2003). Their commercialization can ideally provide an economic incentive for the preservation of the forests, but the viability of this depends on the production systems employed and the extraction intensity (Villalobos and Ocampo 1997; van Weezendonk and Oldenan 2002; Belcher et al. 2005). Experiences with non-timber forest products have been mixed, largely due to difficulties of sustainable harvesting, the economically unviable commercialization of little-known products, and the lack of biological and ecological information on many potentially useful species (Panayotou 1990; Belcher and Schreckenberg 2007). Some methods have been developed to fill the gap of information, such as the Rapid Vulnerability Assessment (RVA) (Watts et al. 1996; Wild and Mutebi 1996). This method uses not only relevant ecological data, but also integrates indigenous information about harvesting, demand, and traditional conservation practices.

While such economically useful families as Poaceae, Fabaceae and Arecaceae are relatively well-known and frequently used, it has been recommended to increase the diversity of plant resources to make their management more attractive and viable (Panayotou 1990). In this sense, more research and practical experience is necessary on families with somewhat lower profile, such as Araceae and Bromeliaceae. Aroids are appreciated mainly as horticultural plants with hundreds of species and cultivars, the most popular being the flamingo flower (Anthurium andraeanum). Least explored is their great potential as medicinal plants. Only some species are known and used for their numerous medicinal properties, compared to the abundant information accumulated for many other species with traditional uses (Plowman 1969; Vickers and Plowman 1984; Bown 1988; Correa and Bernal 1989; Evans and Raffauf 1990; Bennett 1995; Lacaze and Alexiades 1995; Alexiades 1999; Quenevo et al. 1999; Bourdy et al. 2000). A few species are cultivated as food, such as taro (Colocasia esculenta) and tannia or tania (Xanthosoma sagittifolium), which are staple crops in many areas, but only reserve and subsistence food in others (National Academy of Sciences 1975; Hernández and León 1992). In addition, aroids provide toxins and natural pesticides, dyes and crafts, thus increasing their economic and cultural importance (Plowman 1969; Toursarkissian 1980; Bennett 1995; Sandoval et al. 1996).

Although Bromeliaceae have several species that yield edible fruits, only the pineapple (Ananas comosus) is economically important as a food plant (Benzing 1980; Bennett 2000). Fibers from several species are one of the principal products yielded by bromeliads, which form an important income in rural areas (VAIPO 1999, 2000; Ticktin 2002). Several bromeliads have traditional medicinal uses but only for few species this value has been proven. The most important product is bromelain extracted from the fruit of pineapple and 


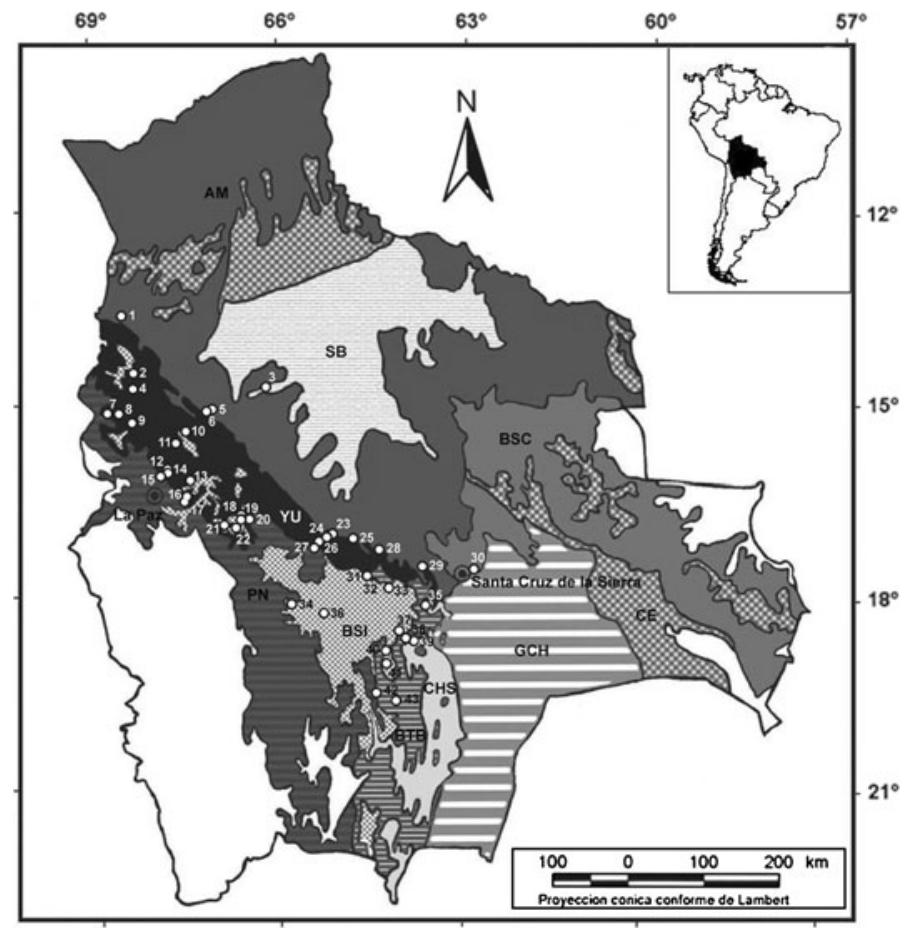

Fig. 1 Map of Bolivia showing the distribution of the ten major ecoregions modified after Ibisch et al. (2003) and the study sites (white dots). AM amazonian rain forest, BSI seasonally deciduous inter-Andean forest, $B S C$ seasonally deciduous Chiquitano forest, $B T B$ subtropical Tucumano-Boliviano forest, $C E$ Cerrado of the Brazilian shield, $C H S$ seasonally deciduous montane Chaco forest, GCH Gran Chaco thorn forest, $P N$ humid northern Puna, $S B$ seasonally flooded savanna, and $Y U$ humid montane Yungas forest

some other bromeliad species (Benzing 1980; Bennett 2000). This is a proteolytic enzyme similar to papain from Carica papaya, currently being marketed by William Rorer, Inc. as Ananase to treat inflammation and related pain. Similar to aroids, bromeliads have numerous wild and cultivated horticultural species. Other uses include dyes, forage, fuel, and water purification, while some species are used as living fences (Martínez-Crovetto 1964; Arenas 1981, 1997; Marzocca 1993; Camacho and Martín 1998; Ríos and Khan 1998; Bennett 2000).

Bolivia, located in the center of South America, includes representative examples of most major terrestrial biomes present on this continent, ranging from tropical rainforest to thorny Chaco scrub and the arid Puna of the high Andes (Ibisch et al. 2003) (Fig. 1). It is an important center for the origin of domestic plant species and of wild relatives of many important food plants, such as potatoes (Solanum spp.), groundnuts (Arachis spp.), cassava (Manihot esculenta), beans (Phaseolus spp.), and hot peppers (Capsicum spp.) (Beck 1998).

The rural population in many parts of the country still actively uses the natural flora as sources of human and animal foods, medicines, construction materials, and fibers. Therefore, much information on the potential uses of many native species can be gathered (Boom 1987). Bolivia has about 135 species of Araceae (Kessler and Croat 1999; Croat and Acebey 2005) and approximately 323 species of Bromeliaceae (Krömer et al. 1999; 
Krömer, unpublished data). Compared to other plant groups, both families have a good status of knowledge in Bolivia due to intensive research on their distribution, diversity, and ecology in recent decades (Ibisch 1996; Bach et al. 1999; Ibisch and Vásquez 2000; Kessler and Krömer 2000; Acebey and Krömer 2001; Kessler 2001, 2002; Krömer et al. 2005, 2006, 2007).

The aim of this study was to gather information on the potential use of species of Araceae and Bromeliaceae in Bolivia for the different ecoregional units of the country. The underlying question was how the potentially useful species of these plant families are distributed in different ecosystems, as a guideline for the prioritization of regional activities aimed at developing their economically and ecologically sustainable use. Because the major ecoregions differentiated here occur throughout the Neotropics, this study is of relevance for the entire continent.

\section{Materials and methods}

A thorough literature search, including numerous unpublished reports, was conducted to compile information on past and current uses of the native species of Araceae and Bromeliaceae in Bolivia, as well as for other neotropical countries (Acebey 2003). A full list of references is available from the first author on request. A total of 74 aroid and 83 bromeliad species were classified into six broad categories of human uses (ornamental, medicinal, food, construction/crafts, fiber production, multipurpose). Since many of these species have more than one use, multiple counts are possible. We defined multipurpose species as those with three or more uses.

Ecological data based on practical criteria to assess the potential for sustainable use as suggested by the RVA method (Watts et al. 1996) were considered. Such criteria are abundance (frequency), life form, geographical distribution, and habitat preference. The data for species was obtained from field studies conducted at 43 sites in the Bolivian Andes (Fig. 1) by Kessler and collaborators (Kessler 2001, 2002). At each site, 8-24 non-permanent plots of $400 \mathrm{~m}^{2}$ each were established, in which all present species of Araceae and Bromeliaceae were recorded together with their growth habits. We categorized these as terrestrial, epiphytic below $2 \mathrm{~m}$, and epiphytic above $2 \mathrm{~m}$. The cover of each species on the ground (terrestrials) or on the trunks and branches (epiphytes) was estimated according to a modified Braun-Blanquet scale $(+=$ rare, $1=1-5 \%$ cover, $2=6-25 \%$, $3=26-50 \%$, $4=51-75 \%, 5=76-100 \%$ ) (for further details see Kessler and Bach 1999; Kessler 2001, 2002). Since most species records showed low cover values ( + , one), we used their frequency, i.e., the percentage of plots at a given study site in which the species was recorded, as a measure of the abundance of the individual species. Species with frequencies $>50 \%$ were considered to be common and of potential economic interest. Habitat preferences were evaluated and classified in two artificial groups as with and without preferences. Species with preference were all detected in one of the following habitats: (a) natural zonal forest, (b) secondary vegetation, and (c) special habitats (vegetation in ravines, on rock faces, ridges). Species without preferences were found in at least three habitats in different combinations in between, including those growing in zonal and secondary vegetation.

In addition, existing knowledge of the geographical distribution based on Missouri Botanical Garden's Tropicos database was analyzed for all species and categorized as follows: endemic, narrow distribution (two or three countries), and wide distribution (four to more countries). Information for the Chiquitano forest and the Gran Chaco was extracted 
Table 1 Major Bolivian ecoregions recognized in the present study (modified after Ibisch et al. 2003)

\begin{tabular}{|c|c|c|c|c|}
\hline Abbr. & Ecoregions & $\begin{array}{l}\text { Mean annual } \\
\text { precipitation (mm) }\end{array}$ & $\begin{array}{l}\text { Number of arid } \\
\text { months }\end{array}$ & $\begin{array}{l}\text { Elevational } \\
\text { range }(\mathrm{m})\end{array}$ \\
\hline YU & Humid montane Yungas forest & $1500-6000$ & $0-2$ & $1000-4200$ \\
\hline AM & Amazonian rain forest & $1000-7000$ & $0-3(2-5)$ & $100-500$ \\
\hline SB & Seasonally flooded savanna & $700-5500$ & $0-5(2-8)$ & $100-200$ \\
\hline $\mathrm{CE}$ & Cerrado of the Brazilian shield & $600-2100(2600)$ & $2-8(0-4)$ & $120-1100$ \\
\hline ВТВ & $\begin{array}{l}\text { Subtropical Tucumano-Boliviano } \\
\text { forest }\end{array}$ & $700-2000$ & $3-5$ & $800-3900$ \\
\hline PN & Humid northern Puna & $400-1000(1600)$ & $3-6$ & $3800-4000$ \\
\hline $\mathrm{BSC}$ & $\begin{array}{l}\text { Seasonally deciduous Chiquitano } \\
\text { forest }\end{array}$ & $600-2300$ & $3-8$ & $100-1400$ \\
\hline CHS & $\begin{array}{l}\text { Seasonally deciduous montane } \\
\text { Chaco forest }\end{array}$ & $700-1000$ & $6-7$ & $700-2000$ \\
\hline BSI & $\begin{array}{l}\text { Seasonally deciduous inter- } \\
\text { Andean forest }\end{array}$ & $<500-700$ & $6-8(-10)$ & $500-3300$ \\
\hline GCH & Gran Chaco thorn forest & $400-900$ & $6-10$ & $200-600$ \\
\hline
\end{tabular}

from Fuentes (1997) and Navarro et al. (1998), since we ourselves did not conduct fieldwork in those regions.

Species and study sites were categorized and assigned to ten major biomes of Bolivia following Ibisch et al. (2003) (Fig. 1, Table 1). These ecoregions are defined by humidity and temperature ranges, and are arranged by ascending number of arid months in Figs. 2, 3,4 and 5 .

\section{Results}

The number of species per ecoregion showed a very clear pattern in Araceae, with by far most species present in the most humid vegetation types, especially Amazonian forest and the humid montane Yungas forest of the eastern Andean slope (Fig. 2). In both regions, hemi-epiphytic species made up roughly half of all species. In some of the dryer vegetation types, such as Chiquitano and Tucumano-Bolivian forest, terrestrial species were dominant (Fig. 2). The absolute and relative number of species with high frequency was highest in Amazonian and Yungas forest, but very low in all other ecoregions. Useful aroids have mostly a wide geographical distribution (Fig. 3), several of these even reaching into Mesoamerica. In the Amazonian region, Chaco, and inter-Andean valleys they mainly showed no clear habitat preferences, whereas in the humid regions such as Yungas, Tucumano-Boliviano and savannas, they showed marked preferences for certain habitats (Fig. 4). The predominance of useful species in the more humid vegetation types (Fig. 5) was especially pronounced for ornamental, medicinal, and food plants. Species providing construction materials and multipurpose species, on the other hand, also showed a notable number of species in some arid regions, such as the Chiquitano forest.

For bromeliads, the pattern was more variable, with highest species richness in the humid montane Yungas and dry inter-Andean forest, followed by Amazonian and Tucumano-Bolivian forest (Fig. 2). Epiphytic species were generally most common, and their frequency was highest in the dry vegetation types and relatively low in the Amazonian. In contrast to the aroids, useful bromeliads had a more restricted geographical distribution. 

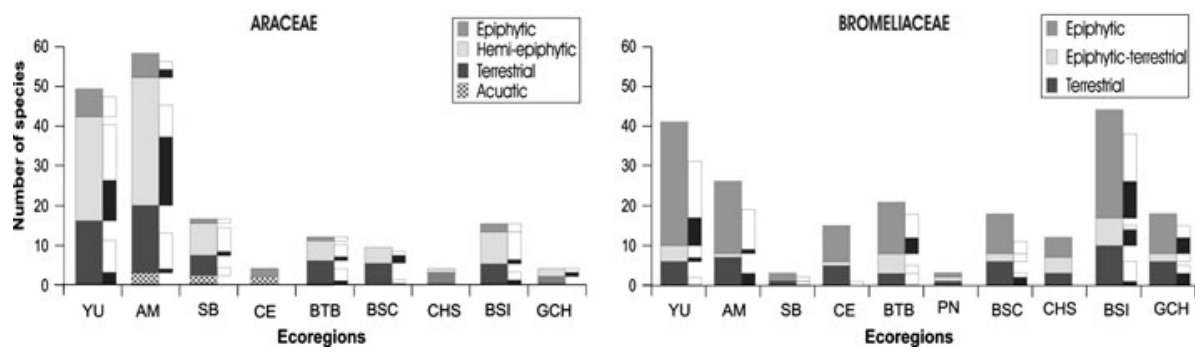

Fig. 2 Total species number and number of species in mayor life form categories (broad bars) as well as frequency (narrow bars) of economically useful Araceae and Bromeliaceae in Bolivia according to ecoregions (arranged by ascending number of arid months). The narrow bars distinguish frequent (black, recorded in $>50 \%$ of all study plots), infrequent (white, $<50 \%$ ) and rare species (no bars, not recorded by us) per life form category. Ecoregions are arranged by ascending number of arid months, their abbreviations follow Table 1

Fig. 3 Proportion of the current geographical distribution of useful species of Araceae $(n=74)$ and Bromeliaceae $(n=83)$. Classified into endemic: only one country (Bolivia), narrow: two or three countries, and wide: more than four countries
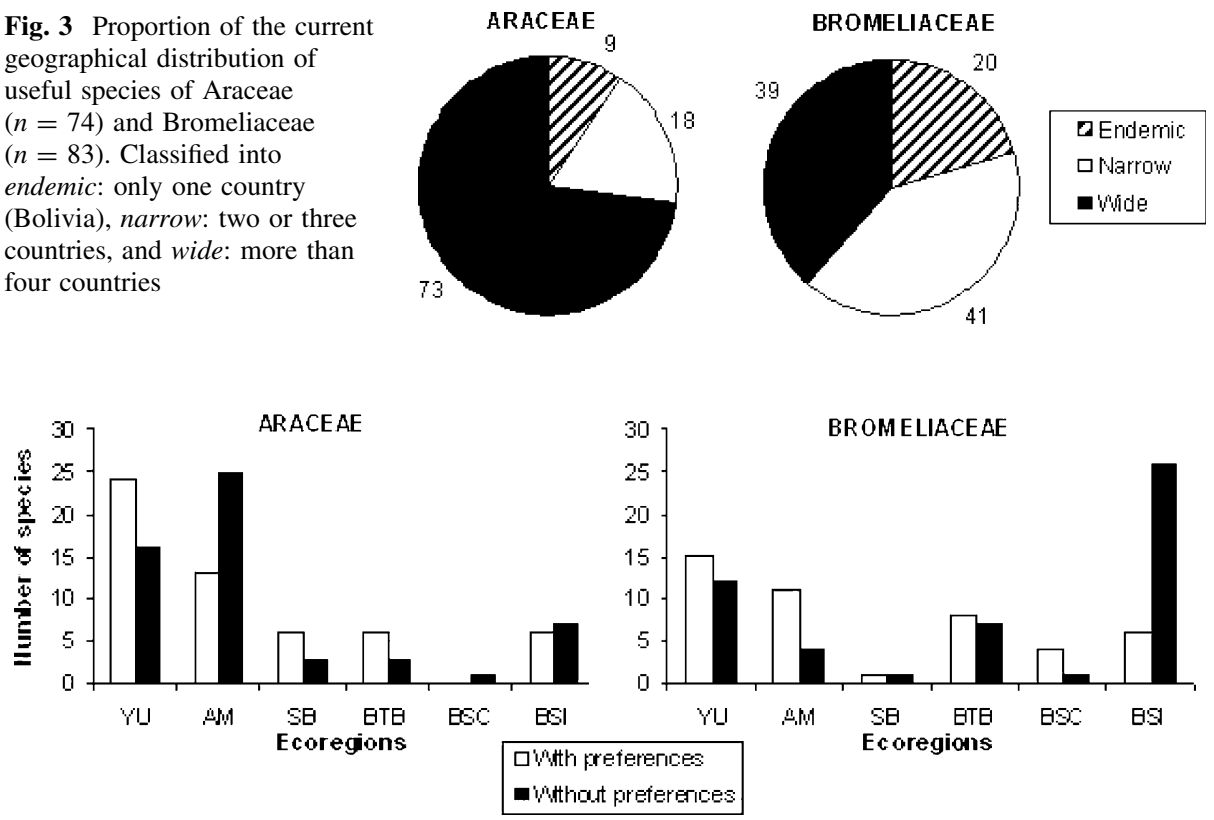

Fig. 4 Habitat preferences of useful species of Araceae and Bromeliaceae in six ecoregions of Bolivia. Ecoregions are arranged by ascending number of arid months, their abbreviations follow Table 1

While the proportion of widely and narrowly distributed species is more or less similar, the number of endemic species is significant (Fig. 3). In general, bromeliads showed preferences for certain habitats in most of the ecoregions studied, although almost no preferences were found in the dry inter-Andean valleys (Fig. 4). Ornamental species were well represented both in the humid montane and dry inter-Andean forests. Medicinal, multi-use, fiber-producing, and food species were most species-rich in the dry forests of the interAndean valleys such as the Gran Chaco and the Chiquitano forest (Fig. 5). Species used as food sources were also well represented in Amazonian forests. 

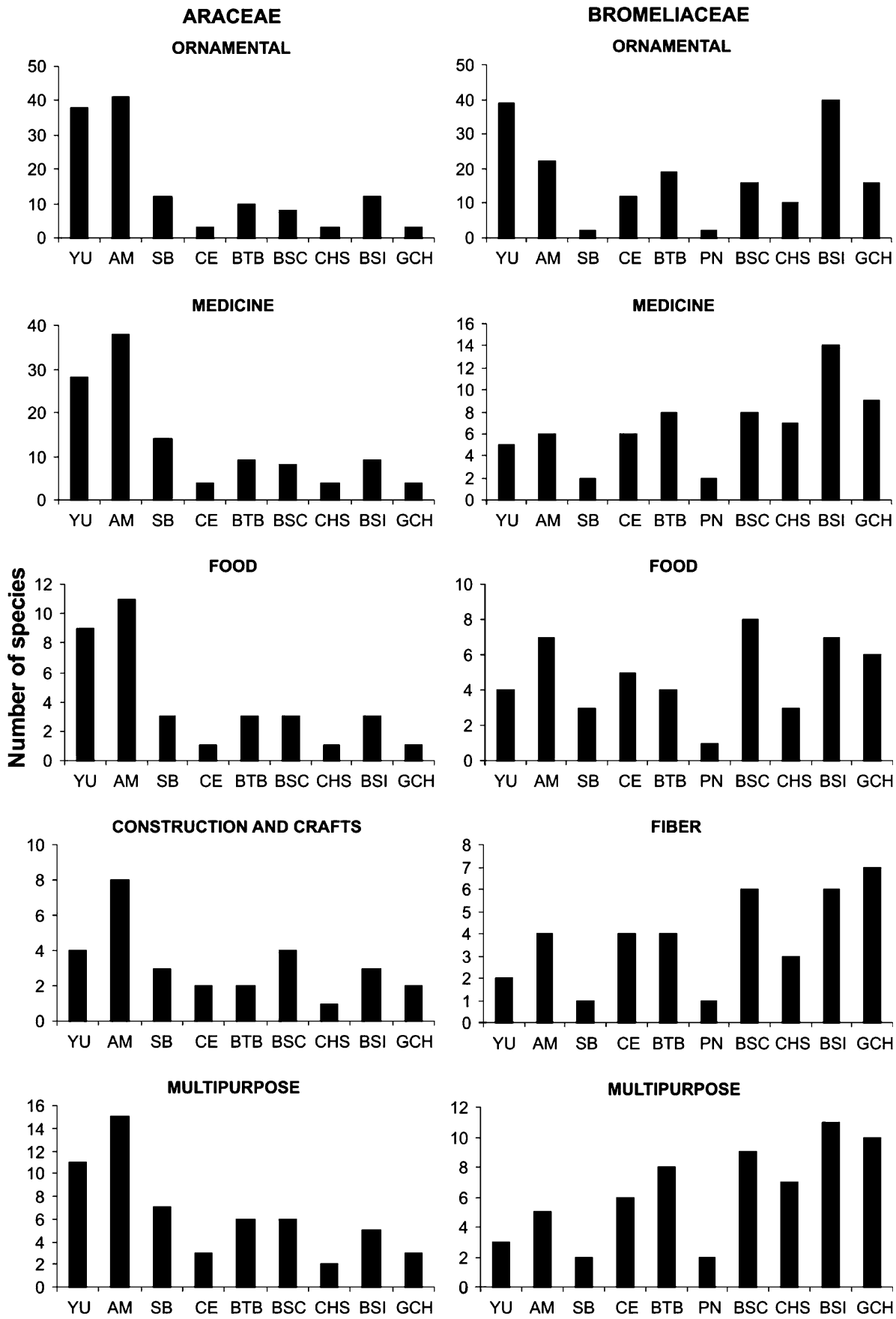

Ecoregions

Fig. 5 Number of economically useful species of Araceae and Bromeliaceae in ten ecoregions of Bolivia. Multiple counts are possible. Multipurpose species contain those with more than three uses. Ecoregions are arranged by ascending number of arid months, their abbreviations follow Table 1 


\section{Discussion}

Bolivia has a striking number of potentially useful species of Araceae and Bromeliaceae, which can provide many non-timber forest products. Both families show distinct distribution patterns and ecological features indicating, thus, that their economic potential may differ among ecoregions.

Araceae were most species-rich and most frequent in the humid lowland and montane forest. This pattern is in accordance with their overall richness pattern (Valencia et al. 1994; Kessler and Croat 1999). Particularly, aroids with medicinal properties have a wide distribution and, for this reason, it is not surprising that this family is considered as one of the most commonly used liana and climbing plant families (Bennett 1992, 1995). Some species, particularly those of Monstera, Syngonium, and Philodendron, which are most diverse in the lowlands, may be abundant in weedy situations (open habitats, road sides, fence rows, plantations) as a possible result of pre-adaptation to such conditions (Croat 1988). When comparing tropical lowland fallows with adjacent mature forests, species richness of aroids showed no reduction (Krömer and Gradstein 2003). Our study shows that the species of aroids most suitable for sustainable utilization are principally located in the Amazonian region. In other regions where species are less frequent, more specialised, and with a narrower distribution, their exploitation may be harmful for the natural populations and, hence, not feasible on a sustainable basis. Ecosystems with more diverse habitats, numerous plant species, and variable life forms, such as montane forests, are generally more vulnerable to human use (Wild and Mutebi 1996).

For medicinal uses, in many cases only certain plant parts (leaves, stems, or sap) are harvested, a practice that allows the survival of the plant and, consequently, has less impact on natural populations (Watts et al. 1996; Ticktin 2004). Since these plants are mostly hemi-epiphytes, their harvesting is straightforward. In contrast, the gathering of aroid roots as sources of construction material is complicated by the fact that these species usually grow high in the canopy. At present, the potential of Araceae as ornamental plants is very little understood in Bolivia, in contrast to the existing high number of species, especially hemi-epiphytic species, that can be easily propagated.

Unlike the aroids, potentially useful bromeliads are best represented in seasonally dry forest habitats, with the exception of ornamental species, which also occur in humid montane forests, even though they tend to be rare there and are probably best cultivated for commercialisation rather than relying on collecting from natural populations (Acebey et al. 2007). One of the first requirements for the sustainable use of bromeliads is that they are present in large populations (Wolf and Konings 2001). Ideally, time-consuming case studies of density are needed for each species, but we may use some indirect indicators such as frequency to estimate species abundance. In general, we found that bromeliads of inter-Andean forests are more frequent and have a relatively wider distribution and fewer preferences for specific habitats. Therefore, they may be more suitable for the sustainable use of natural populations than species of humid forests. However, more detailed studies at the species level are needed to identify specific guidelines for a long-time use. For example, it might be advisable to only gather abundant and spatially homogeneously dispersed species, and to harvest at the lower parts of the trees (Wolf and Konings 2001). Most likely, the bromeliads of dry Chaco and Chiquitano forest have similar ecological characteristics to those in the inter-Andean forests and the same implications for sustainable use.

The use and commercialisation of products from the Bromeliaceae family is more popular in drier than in humid regions, due to the presence of some multipurpose species. 
Particularly, the production of handicrafts based on the fibres of Bromelia serra, B. hieronymi, and Pseudananas sagenarius is a locally important economical activity in the Chiquitano and Chaco regions, providing an additional income of about 20 US\$ per year per involved family (VAIPO 1999, 2000). Terrestrial species, such as B. serra, $P$. sagenarius, and Aechmea distichanta are locally very frequent and abundant, and thrive in secondary and disturbed vegetation (Acebey 2003). Therefore, these species may represent an important economical source in forest areas that are otherwise fairly devoid of natural plant resources (at least once the valuable timber trees have been extracted, as is already the case in most of Bolivia). Furthermore, their terrestrial growth in large colonies allows efficient gathering and makes these species less vulnerable, as shown for Aechmea magdalenae in Mexico, which can tolerate higher levels of harvest (Ticktin 2004). Some additional benefits obtained from these plants, such as fruits, seeds, and vegetative shoots, are usually only consumed locally and have not been commercialised (Hilgert 1999). Some fruits may be important genetic resources of wild species that actually are little-known, such as relatives of the pineapple (A. comosus). Traditional medicinal species of the Bromeliaceae mostly belong to the genera Bromelia and Tillandsia, however, no detailed studies exist. Unfortunately, the harvest of vegetative shoots for food and roots for medical treatments is not sustainable because this completely eliminates individual plants.

In conclusion, we found that Araceae and Bromeliaceae have a considerable local, regional, and national potential providing non-timber forest products. International commercialisation may only be feasible for certain and very common ornamental species and for handicrafts that can be successfully sold, e.g. via the Internet. Strikingly, the potential use for Bromeliaceae is clearly highest in seasonally dry forest ecoregions, both in the lowlands (Chiquitano, Chaco forest) and in the Andes (inter-Andean dry forest). These habitats are usually given less conservation importance than the overall more species-rich humid forests (Amazonia, Yungas humid Andes). Due to their more favourable living conditions, however, seasonally dry forest regions are much more densely inhabited by humans and have suffered more extensive habitat destruction. In this context, the high frequency of potentially useful bromeliads even in disturbed habitats is encouraging. While the production and commercialisation of handicrafts is certainly limited by market needs, we believe that efficient marketing may greatly increase the economical value of these resources. It might, for example, be possible to establish hammocks and bags made from bromeliad fibres alongside the popular alpaca pullovers as tourist souvenirs. In contrast, the Araceae, which occur mainly in humid forest regions, are of particular local importance. A wider commercialisation of these resources in a profitable way is unlikely, but a more efficient use may increase the livelihood of local human populations. Evidently, the uses of Araceae and Bromeliaceae are manifold and could be greatly increased through efficient management, with different strategies for the two plant families in the different ecoregions.

Acknowledgments We thank K. Bach, J.A. Balderrama, J. Bolding, J. Fjeldså, J. Gonzales, A. Green, S.K. Herzog, B. Hibbits, S. Hohnwald, I. Jimenez, J.-C. Ledesma, M. Olivera, A. Portugal, J. Rapp, J. Rodriguez, and M. Sonnentag for help and good companionship during field work; T. Croat, H. Luther, E. Gross, and P.L. Ibisch for specimen identification and for providing site and distributional data; and R. Coates for valuable comments and corrections. This study would have been impossible without the logistic support by the Herbario Nacional de Bolivia, La Paz, in particular by S.G. Beck, M. Cusicanqui, A. de Lima, R. de Michel, and M. Moraes. For working and collecting permits we thank the Dirección Nacional de Conservación de la Biodiversidad (DNCB), La Paz. Field work was supported by the Deutsche Forschungsgemeinschaft, the A.F.W. Schimper-Stiftung, and the DIVA project under the Danish Environmental Programme. 
Open Access This article is distributed under the terms of the Creative Commons Attribution Noncommercial License which permits any noncommercial use, distribution, and reproduction in any medium, provided the original author(s) and source are credited.

\section{References}

Acebey A (2003) Evaluación del potencial de las familias Araceae y Bromeliaceae como fuente de recursos no maderables en Bolivia. MSc thesis, Georg-August-Universität, Göttingen

Acebey A, Krömer T (2001) Diversidad y distribución vertical de epifitas en los alrededores del campamento río Eslabón y de la laguna Chalalán, Parque Nacional Madidi, Depto. La Paz, Bolivia. Rev Soc Bol Bot 3:104-123

Acebey A, Kessler M, Maass BL (2007) Potencial de aprovechamiento de Araceae y Bromeliaceae como recursos no maderables en el bosque montano húmedo del Parque Nacional Cotapata, Bolivia. Ecol Bol 42:4-22

Akerele O, Heywood V, Synge H (eds) (1991) Conservation of medicinal plants. Cambridge University Press, Cambridge

Alexiades MN (1999) Etnobotany of the Ese Eja: plants, health, and change in an Amazonian society. Dissertation, University of New York

Arenas P (1981) Etnobotánica lengua-Maskoy. Fundación para la educación, la ciencia y la cultura, Buenos Aires, Argentina

Arenas P (1997) Las bromeliáceas textiles utilizadas por los indígenas del Gran Chaco. Parodiana 10:113139

Bach K, Kessler M, Gonzales J (1999) Caracterización preliminar de los bosques deciduos andinos de Bolivia en base a grupos indicadores botánicos. Ecol Bol 32:7-22

Beck SG (1998) Forestry inventory of Bolivia—an indispensable contribution to sustainable development. In: Barthlott W, Winiger M (eds) Biodiversity-a challenge for development research and policy. Springer, Berlin

Belcher B (2003) What isn't an NTFP? Int For Rev 5:161-168

Belcher B, Schreckenberg K (2007) Commercialization of non-timber forest products: a reality check. Dev Policy Rev 25:355-377

Belcher B, Ruíz Pérez M, Achdiawan R (2005) Global patterns and trends in the use and management of commercial NTFPs: implications for livelihoods and conservation. World Dev 33:1435-1452

Bennett B (1992) Use of epiphytes, lianas and parasites by the Shuar people of Amazonian Ecuador. Selbyana 13:99-114

Bennett B (1995) Ethnobotany and economic botany of epiphytes, lianas, and other host-dependent plants: an overview. In: Lowman MD, Nadkarni NK (eds) Forest canopies. Academic Press, San Diego

Bennett B (2000) Ethnobotany of Bromeliaceae. In: Benzing DH (ed) Bromeliaceae: profile of an adaptative radiation. Cambridge University Press, Cambridge

Benzing DH (1980) The biology of the bromeliads. Mad River Press, Eureka

Boom BM (1987) Ethnobotany of the Chácobo indians, Beni, Bolivia. Adv Econ Bot 4:1-68

Bourdy G, De Walt SJ, Chávez de Michel LR, Roca A, Deharo E, Muñoz V, Valderrama L, Quevedo C, Jiménez A (2000) Medicinal plants uses of the Tacana, an Amazonian Bolivian ethnic group. J Ethnopharmacol 70:87-109

Bown D (1988) Aroids. Plants of the Arum family. Timber Press, Oregon

Camacho R, Martín K (1998) Uso campesino de especies arbustivas y arbóreas forrajeras en Bolivia. Programa de Bosques nativos Andinos PROBONA, La Paz, Bolivia

Correa JE, Bernal HY (1989) Especies vegetales promisorias: de los países del Convenio Andrés Bello. Tomo I. Secretaria Ejecutiva del Convenio Andrés Bello (SECAB), Ministerio de Educación y Ciencia España, Junta del Acuerdo de Cartagena (JUNAC), Bogotá

Croat TB (1988) Ecology and life forms of Araceae. Aroideana 11:4-55

Croat TB, Acebey A (2005) New species of Araceae from Bolivia and the tropical Andes. Novon 15:80-103

De Beer J (1990) Subsistence use and market value of non-timber forest products: the example from southeast Asia. In: Wegge P (ed) Status and potential of non-timber products in the sustainable development of tropical forests. Proceedings of the international seminar, International Tropical Timber Organization, Kamakura

Evans R, Raffauf RF (1990) The healing forest: medicinal and toxic plants of the Northwest Amazonia. Dioscorides Press, Portland 
FAO (1995) Report of the international expert consultation on non-wood forest products. Non wood forest products 3. FAO, Rome

FAO (1996) The state of the world's plant genetic resources for food and agriculture. FAO, Rome

Fuentes A (1997) Estudio Fitosociológico de los principales tipos de vegetación de la Estancia San Miguelito. Prov. Nuflo de Chávez, Santa Cruz, Bolivia. Thesis de licenciatura. Universidad G. René Moreno, Santa Cruz de la Sierra

Hernández JE, León J (1992) Cultivos marginados: otra perspectiva de 1492. Colección FAO: producción y Protección Vegetal No 26. FAO, Rome

Hilgert NI (1999) Plantas comestibles de los Yungas Meridionales de la Argentina. An Jard Bot Madr $57: 23-33$

Ibisch PL (1996) Neotropische Epiphytendiversität: das Beispiel Bolivien. M. Galunder-Verlag, Wiehl

Ibisch PL, Vásquez R (2000) Illustrated catalogue of the Bromeliaceae of Bolivia. Illustrated biodiversity of Bolivia, vol 1 (CD-ROM 1.0). Editorial F.A.N., Santa Cruz de la Sierra

Ibisch PL, Beck SG, Gerkmann B et al (2003) Ecoregiones de Bolivia. In: Ibisch PL, Mérida G (eds) Biodiversidad: la riqueza de Bolivia. Estado de conocimiento y conservación. Ministerio de Desarrollo Sostenible, Editorial F.A.N., Santa Cruz de la Sierra

Kessler M (2001) Patterns of diversity and range size of selected plant groups along an elevational transect in the Bolivian Andes. Biodivers Conserv 10:1897-1920

Kessler M (2002) Species richness and ecophysiological type among Bolivian bromeliad communities. Biodivers Conserv 11:987-1010

Kessler M, Bach K (1999) Using indicator families for vegetation classification in species-rich Neotropical forests. Phytocoenologica 29:485-502

Kessler M, Croat TB (1999) State of knowledge of Bolivian Araceae. Selbyana 20:224-234

Kessler M, Krömer T (2000) Patterns and ecological correlates of pollination modes among Bromeliad communities of Andean forests in Bolivia. Plant Biol 2:659-669

Krömer T, Gradstein SR (2003) Species richness of vascular epiphytes in two primary forest and fallows in the Bolivian Andes. Selbyana 24:190-195

Krömer T, Kessler M, Holst BK et al (1999) Checklist of Bolivian Bromeliaceae with notes on species distribution and levels of endemism. Selbyana 20:201-223

Krömer T, Kessler M, Gradstein SR et al (2005) Diversity patterns of vascular epiphytes along an elevational gradient in the Andes. J Biogeogr 32:1799-1809

Krömer T, Kessler M, Herzog SK (2006) Distribution and flowering ecology of bromeliads along two climatically contrasting elevational transects in the Bolivian Andes. Biotropica 38:183-195

Krömer T, Kessler M, Gradstein SR (2007) Vertical stratification of vascular epiphytes in submontane and montane forest of the Bolivian Andes: the importance of the understory. Plant Ecol 189:261-278

Lacaze D, Alexiades M (1995) Salud para todos: plantas medicinales y salud indígena en la cuenca del río Madre de Dios, Perú. Un manual práctico. Cuadernos de Capacitación Popular 46. Federación Nativa del Río Madre de Dios y Afluentes (FENAMAD) y Centro de Estudios Regionales Andinos "Bartolomé de las Casas" (CBC), Madre de Dios

Martínez-Crovetto R (1964) Estudios etnobotánicos. I. Nombres de plantas y su utilidad, según los indios tobas del este del Chaco. Bonplandia 1:279-333

Marzocca A (1993) Index de Plantas colorantes tintóreas y curtientes: manual de las especies de Argentina. Serie de la academia nacional de agronomía y veterinaria No 9, Buenos Aires

National Academy of Sciences (1975) Underexploited tropical plants with promising economic value. Report of an Ad Hoc Panel of the Advisory Committee of Technology Innovation Board on Science and Technology for international Development Commission on International Relation, Washington DC

Navarro G, Fuentes A, Guerrero J et al (1998) Tipificación y caracterización de los ecosistemas del Parque Nacional Kaa-Iya del Gran Chaco (Departamento de Santa Cruz, Bolivia). Proyecto Kaa-Iya, componente Plan de Manejo. Informe Técnico CABI-WCS, Santa Cruz de la Sierra

Panayotou T (1990) Introduction: multiproduct forest management—a key to sustainability? In: Wegge P (ed) Status and potential of non-timber products in the sustainable development of tropical forests. Proceedings of the international seminar. International Tropical Timber Organization, Kamakura

Panayotou T, Ashton PS (1992) Not by timber alone. Economics and ecology for sustaining tropical forests. Island Press, Washington

Peters CM, Balick MJ, Kahn F et al (1989) Oligarchic forests of economic plants in Amazonia: utilization and conservation of an important tropical resource. Conserv Biol 3:341-349

Phillips O, Gentry AH, Reynel C et al (1994) Quantitative ethnobotany and Amazonian conservation. Conserv Biol 8:225-248

Plowman T (1969) Folk uses of new world aroids. Econ Bot 23:97-122 
Quenevo C, Bourdy G, Gimenez A (1999) Tacana. Conozcan nuestros árboles, nuestras hierbas. Centro de información para el desarrollo CID. UMSA-CIPTA-IRD-FONAMA-EIA, La Paz

Ríos R, Khan B (1998) List of etnobothanical uses of Bromeliaceae. J Brom Soc 48:75-87

Sandoval P, Choque J, Uriona P (1996) Cartilla popular sobre las plantas útiles de los Alteños de MizqueCochabamba. Centro de Investigaciones Botánicas y Ecológicas CIBE-Universidad Mayor de San Simón, Cochabamba

Ticktin T (2002) The history of Ixtle in Mexico. Econ Bot 56:92-94

Ticktin T (2004) Review: the ecological implications of harvesting non-timber forest products. J Appl Ecol 41:11-21

Toursarkissian M (1980) Plantas medicinales de la Argentina: sus nombres botánicos, vulgares, usos y distribución geográfica. Editorial Hemisferio Sur, Buenos Aires

VAIPO (1999) Identificación de necesidades TCO Chiquitania Ayorea, Area Tobita. Viceministerio de Asuntos Indígenas y Pueblos Originarios, La Paz

VAIPO (2000) Informe de necesidades para el territorio indígena Weenhayek, Tarija, Bolivia. Viceministerio de Asuntos Indígenas y Pueblos Originarios. Documento preliminar, La Paz

Valencia R, Balslev H, Paz y Miño G (1994) High tree alpha-diversity in Amazonian Ecuador. Biodiv Conserv 3:21-28

van Weezendonk LHT, Oldenan RAA (2002) Kronendak notes on canopy farming, in combination with conventional forestry. Canopy farming@ Kronendak: http://www.treemail.n1/kronendak/cic.htm. Cited 15 Jan 2007

Vedeld P, Angelsen A, Sjaastad E et al (2004) Counting on the environment: forest incomes and the rural poor. World Bank, Washington

Vickers WT, Plowman T (1984) Useful plants of the Siona and Secoya Indians of Eastern Ecuador. Botany, new series No 15. Field museum of natural history. Fieldiana 15:1-63

Villalobos R, Ocampo R (1997) "Actas": productos no maderables del bosque en Centroamérica y el Caribe. Serie Técnica: Eventos especiales $N^{\circ} 1$. Proyecto de Conservación para el Desarrollo Sostenible en América Central. Centro Agronómico Tropical de Investigación y Enseñanza CATIE, Turrialba

Watts J, Scott P, Mutebi J (1996) Forest assessment and monitoring for conservation and local use: experience in three Ugandan national parks. In: Carter J (ed) Recent approaches to participatory forest resource assessment. Rural development forestry study guide 2. ODI, London

Wild RG, Mutebi J (1996) Conservation through community use of plant resources: establishing collaborative management at Bwindi impenetrable and Mgahinga Gorilla National Parks, Uganda. People and plants working paper 5. UNESCO, Paris

Wolf JHD, Konings CJF (2001) Toward the sustainable harvesting of epiphytic bromeliads: a pilot study from highlands of Chiapas, Mexico. Biol Conserv 101:23-31 